\title{
An update to middle east respiratory syndrome coronavirus and risk of a pandemic in 2019
}

Kazhal Mobaraki and Jamal Ahmadzadeh*

Social Determinants of Health Research Center, Urmia University of Medical Sciences, Urmia, Iran

\section{Dear Editor,}

Based on available data and current situation of Middle East respiratory syndrome coronavirus (MERS-CoV) on disease outbreak news of World Health Organization (WHO) website, 2374 MERS$\mathrm{CoV}$ cases including 823 associated deaths (globally case fatality rate was $34.66 \%)$ occurred from 27 countries in worldwide [1]. Constant incidence of a large number of MERS-CoV cases and high lethality related to MERS-CoV infection indicate that this infection must be considered as a threat to global health security with high intensity and lethality. Since there is not still a vaccine or specific treatment to prevention of MERS-CoV [2], all at-risk individuals in involved

Table 1. Sample characteristics of 85 MERS patients in the worlds in 2019

\begin{tabular}{|c|c|c|c|}
\hline Characteristic & Levels & $\mathbf{n}$ & $\%$ \\
\hline \multirow{2}{*}{ Age (year) } & $\leq 50$ & 8 & 42.1 \\
\hline & $>50$ & 11 & 57.9 \\
\hline \multirow{2}{*}{ Gender } & Male & 17 & 89.5 \\
\hline & Female & 2 & 10.5 \\
\hline \multirow{2}{*}{ Reporting Country } & Oman & 13 & 15.3 \\
\hline & Saudi Arabia & 72 & 84.7 \\
\hline \multirow{11}{*}{ City of Residence } & Al-Qassim & 5 & 5.9 \\
\hline & Asir & 1 & 1.2 \\
\hline & Jeddah & 3 & 3.5 \\
\hline & Madinah & 1 & 1.2 \\
\hline & Makkah & 1 & 1.2 \\
\hline & Najran & 1 & 1.2 \\
\hline & North Al-Batinah & 9 & 10.6 \\
\hline & Quryiat & 1 & 1.2 \\
\hline & Riyadh & 58 & 68.2 \\
\hline & South sharquia & 4 & 4.7 \\
\hline & Tabouk & 1 & 1.2 \\
\hline \multirow{2}{*}{ Health Care Worker } & Yes & 11 & 12.9 \\
\hline & No & 74 & 87.1 \\
\hline \multirow{2}{*}{ Comorbidities } & Yes & 48 & 56.5 \\
\hline & No & 37 & 43.5 \\
\hline \multirow{3}{*}{ Exposure to Camels } & Yes & 21 & 24.7 \\
\hline & No & 13 & 15.5 \\
\hline & Not reported & 51 & 60.0 \\
\hline \multirow{3}{*}{ Camel Milk Consumption } & Yes & 20 & 23.5 \\
\hline & No & 12 & 14.1 \\
\hline & Not reported & 53 & 62.4 \\
\hline \multirow{3}{*}{ Exposure to MERS-CoV Cases } & Yes & 53 & 62.4 \\
\hline & No & 2 & 2.4 \\
\hline & Not reported & 30 & 35.3 \\
\hline \multirow{2}{*}{ Final Outcome } & Dead & 14 & 16.5 \\
\hline & Survived & 71 & 83.5 \\
\hline
\end{tabular}

countries are better to have a focus on preventive measures. Every year, millions of muslims travel to epicenter of this infection in Saudi Arabia to perform Hajj. The pilgrims on return to home hold ceremony which was attended by family and friends. Oriental etiquette to want to share hospitality with others increases transmission of probable MERS$\mathrm{CoV}$ to others. This represents that MERS-CoV capable transmit from human-to-human but the virus does not pass easily from person to person unless when an individual is in close contact [3]. The current epidemiological status of MERS-CoV from 2019-01-01 until 2019-0415 presented in table 1 . This data showed that during the mentioned period the most of MERS-CoV patients were male (89.5\%) with age $>50$-year-old (57.9\%). After 8 years from the start of the MERS-CoV pandemic, Saudi Arabia (most MERS-CoV cases occurred in the Riyadh city), $56.5 \%$ had comorbidities and $12.9 \%$ were health care worker, $24.7 \%$ had history for exposure to camels, $23.5 \%$ reported that they had camel milk consumption and $62.4 \%$ had a positive history for exposure to MERS-CoV Cases. During the course of this study, 14 people with MERS-CoV died and remaining survived. Thus, the latest case fatality rate related to MERS-CoV infection was $16.47 \%$.

Overall, In today's "global village", there is a probability of MERS$\mathrm{CoV}$ epidemic at any time and in any place without prior notice. Thus, health systems in all involved countries should implement better triage systems for potentially imported cases of MERS-CoV to prevent large epidemics.

\section{Declaration of conflicting interests}

The author(s) declared no potential conflicts of interest with respect to the research, authorship, and/or publication of this article.

\section{Funding}

The author(s) received no financial support for the research, authorship, and/or publication of this article.

\section{References}

1. World health organization. Emergencies preparedness, response: MERS-CoV Disease outbreak news [updated in 2019-04-16]. Available from: http://www.who.int/csr/don/ archive/disease/coronavirus infections/en/

${ }^{\star}$ Correspondence to: Jamal Ahmadzadeh, Epidemiologist in Social Determinants of Health Research Center, Urmia University of Medical Sciences, Resalat Street, Urmia, Iran, Tel: +98-9143444924, Fax: +98-04432240642; E-mail: ahmadzadeh.j@umsu.ac.ir

Received: April 16, 2019; Accepted: April 26, 2019; Published: April 30, 2019 
2. Song Z, Xu Y, Bao L, Zhang L, Yu P, et al. (2019) From SARS to MERS, Thrusting Coronaviruses into the Spotlight. Viruses 11: 59. [Crossref]
3. Habibzadeh F (2014) Hajj ritual and risk of a pandemic. Am J Infect Control 42: 84. [Crossref]

Copyright: $@ 02019$ Mobaraki K. This is an open-access article distributed under the terms of the Creative Commons Attribution License, which permits unrestricted use, distribution, and reproduction in any medium, provided the original author and source are credited. 